\title{
Immigrants' Religious Transmission in Southern Europe: Reaction or Assimilation? Evidence from Italy
}

\author{
Francesco Molteni ${ }^{1}$ (D) Iraklis Dimitriadis $^{1}$
}

Accepted: 19 February 2021 / Published online: 23 March 2021

(C) The Author(s) 2021, corrected publication 2021

\begin{abstract}
In recent decades, scholars have been increasingly interested in analysing immigrants' religiosity in Europe. In this article, we provide evidence about how the patterns of religious transmission are shaped by religious characteristics of both the origin and receiving contexts. We do so by focusing on Italy, which is both an almost homogeneously Catholic country and a fairly recent immigration destination, and by analysing three different dimensions of religiosity: service attendance, prayer and importance of religion. By relying on the "Social conditions and integration of foreign citizens" survey (ISTAT, 2011-2012), we fill an important theoretical and geographical gap by analysing differences in religiosity between parents and children. We claim that immigrant groups who share many characteristics with the natives tend to assimilate by adopting the same patterns of transmission (for example, Romanians in Italy). In contrast, immigrants who come from very different religious contexts, such as the Muslim Moroccan group, strongly react to this diversity by emphasising the transmission of their own religiosity. If, instead, immigrants come from a very secular country, such as Albania, they also tend to replicate this feature in the receiving countries, thus progressively weakening their religiosity and also their denominational differences. Overall, it is the interplay between origin and destination context which matters the most in shaping the patterns of religious transmission.
\end{abstract}

Keywords Immigration · Religiosity $\cdot$ Religious transmission · Italy · Assimilation · Reaction

\section{Introduction}

In recent decades, scholars have been increasingly interested in analysing immigrants' religiosity in Europe, paying particular attention to its intergenerational transmission

Francesco Molteni

francesco.molteni@unimi.it

1 Dipartimento di Scienze Sociali e Politiche, Università degli Studi di Milano, Via Conservatorio, 7-20122, Milano, Italy 
(Cesari, 2003; Fleischmann \& Phalet, 2012; De Hoon \& van Tubergen, 2014; Jacob, 2020; Jacob \& Kalter, 2013; Maliepaard \& Lubbers, 2013; Roy, 2004; Soehl, 2017). In contrast to the US social science literature that sees immigrants' religion as means to facilitate integration (Foner \& Alba, 2008), in Western Europe religion has received growing attention due to the problems linked to Muslim immigrants' and their children's difficulties in adapting to the receiving context (Buijs \& Rath, 2006).

Against this general interest, the lack of studies focusing explicitly on religiosity in Southern European countries is puzzling. In fact, countries from this region share numerous similarities for what concerns immigration patterns - such as the evolution of migration flows, immigrants' demographic characteristics, their integration in the labour market as well as migration policies and integration outcomes (King, 2000; Peixoto et al., 2012; Ambrosini, 2018; Fellini, 2018) — that make them highly interesting, albeit under-researched, case studies.

As far as Italy is concerned, many recent works have argued that immigrant groups face hardships in terms of socio-economic integration into the new society (Ambrosini, 2013; Fellini \& Guetto, 2019; Zanfrini, 2020). Moreover, their offspring's performance in the education system and access to the labour market are often troublesome. For instance, Zanfrini (2019) shows that children of poor migrant families achieve lower competencies at school, need more time to finish their course of studies and are more likely to leave school. These facts increase their risk of obtaining a bad job and less qualified professions. These integration problems are shown to be particularly relevant in the case of immigrants with greater religious intensity (Guetto \& Fellini, 2017), especially following the terrorist attacks in various European cities (Ricucci, 2017).

Generally speaking, religious beliefs and practices as well as many other values, attitudes and behavioural patterns, are largely transmitted to children by their parents who are the principal agents in the socialisation processes (Glass et al., 1986; Maliepaard \& Lubbers, 2013). Although some literature has focused on religious transmission among immigrants and second generations, few studies have evaluated comparatively the processes of parents-to-children religious transmission between native and immigrant populations. On the one hand, previous work focusing on countries other than Italy has suggested that ethnic minority adolescents (particularly Muslims) are more religious than their native-majority counterparts (van Tubergen \& Sindradóttir, 2011; Güngör et al., 2012; De Hoon \& van Tubergen, 2014; Soehl, 2017). On the other hand, it has been claimed that ethnic minority parents are more successful in transmitting religiosity than native ones (De Hoon \& van Tubergen, 2014).

Although there is an increasing number of studies focusing on immigrants in Western and Northern Europe, so far as is known, this is the first attempt to study this topic in one of the Southern European countries (Greece, Italy, Portugal, Spain). Rather than just filling a geographical gap, the study provides insights on a context - Italywhere immigrant populations face a relatively strong and homogeneous Christian majority, unlike what happens in Northern and Central European countries. This feature, which is also shared with the other southern European countries, allows us to make a theoretical contribution to the debate on whether religion should be perceived as a bridge or barrier for integration, as well as on the interplay between religious contexts of origin and destination. This is of great relevance in a country where anti-immigration attitudes are widespread (Molteni, 2019) and where affiliation to the Muslim faith is 
assumed to be increasingly connected to discrimination, thus affecting the integration outcomes of this group of migrants (Zanfrini, 2019, 2020).

In order to address this issue, we perform two main analytical choices. On the one side, we adopt a multidimensional definition of religiosity to shed light on the differences between a public practice (service attendance), a private practice (prayer) and a measure tied to the respondent's identity (the importance attached to religion). On the other side, we follow De Hoon and van Tubergen's (2014) proposal for adopting a multiple-group perspective that considers both minority and majority groups and permits cross-group comparisons. Using this strategy, we are able to achieve a twofold objective. Firstly, to analyse whether transmission from parents to children is stronger or weaker in immigrant vs. native families, and, secondly, to provide evidence on which immigrant groups are more effective in transmitting religiosity. Given the structure of the work, we highlight the differences between immigrants and native population, and among the most numerous immigrant groups in Italy (Moroccans, Romanians, and Albanians). Our results show that immigrants coming from countries that share religious characteristics with the receiving context tend to replicate the patterns of the natives, whereas immigrants coming from very different countries, both in terms of denomination and levels (as for Moroccans) put stronger emphasis in transmitting their religiosity to children.

In the following section, we introduce the Italian context and we illustrate its migration history and the religious and societal characteristics of the three groups under study. We then review the literature about the religious transmission of immigrants while highlighting the dichotomy between assimilation theory and reactive ethnicity theory. After this, we present the research design and advance the hypotheses, as well as the data and the methods we adopt to test them. Finally, we provide the results and discuss them. In doing this, we situate the Italian case in a broad theoretical framework which potentially includes also the other southern European countries.

\section{Origin and destination contexts: societal aspects and religious characteristics}

Several features of both the origin and receiving contexts, including political settings and arrangements between the state and religious groups, may shape immigrant behaviour and their effort to transmit religious values, beliefs, and behaviours. This complexity makes it necessary to consider both context and group characteristics, as well as the interplay between origins and destinations.

\section{Italy as a destination country}

This study focuses on Italy, which presents two very desirable key features for the theoretical development of the theories about immigrants' religiosity. On the one side, notwithstanding the advancing secularization in Italy, the country remains very religiously homogeneous, as almost $90 \%$ of the population declare to belong to the Catholic religion (Vezzoni \& Biolcati-Rinaldi, 2015). On the other side, immigration was almost an unknown phenomenon before the 1970s and only in recent decades Italy started to become a migration destination (Ambrosini, 2018). 
The religiosity of Italians, although high if compared to their counterparts in most European countries (Vezzoni \& Biolcati-Rinaldi, 2015; Ricucci, 2017), is on the decline. This generally declining trend is recognized to have passed through different stages and fluctuations (Garelli, 1991; Cesareo et al., 1995) but what is central for our reasoning is that the religious decline, which appeared to slow down in the 1980s, has started again (Pisati, 2000; Vezzoni \& Biolcati-Rinaldi, 2015).

For what concerns Italy as immigration destination, instead, it needs to be stressed that, until recently, the Italian population has been characterized by a high degree of homogeneity in terms of racial and religious characteristics (Fullin, 2016). It is since the late $1970 \mathrm{~s}$ and $1980 \mathrm{~s}$ that the country started to become a migration destination. In 2020 , the immigrant population in Italy is 5,306,548 ${ }^{1}$. The largest immigrant group are the Romanians $(1,207,919)$, followed by the Albanians $(440,854)$ and the Moroccans $(432,458)$. People belonging to these migrant groups have traditionally found work in the so-called 3D jobs (dirty, dangerous, demeaning), mostly agriculture, construction and domestic services (Fullin, 2016). In the last 20 years, Italy has become the second major EU receiving country (after Spain), and for the first time in its recent history, it counts a great number of second generation and Italian-naturalised people.

As for immigrants' acceptance in the Italian society, it has been argued that the principal discriminatory factor has traditionally been their segregation in the secondary sector of the labour market and poor perceptions about their (positive) economic performance (Bonizzoni, 2018; Fullin \& Reyneri, 2011). Immigrants also experience discrimination when accessing housing (Membretti \& Quassoli, 2015) and are sometimes excluded from social policies at the local level (Ambrosini, 2013). Aside from labour market entry, integration outcomes in Italy - as well as in the other Southern European countries - have been often considered limited, whereas fear and concern around immigration have often characterised public perceptions and attitudes. This is increasingly relevant in Italy, where there is a deep divergence between perception and statistical evidence, as studies on public debate on immigration and asylum show (Ambrosini, 2018).

\section{Immigrant groups in Italy: religious and social characteristics}

During the last two decades, it can be claimed that Islam in Italy, as in Europe generally, has become a fundamental source of social divide (Ricucci, 2017), representing a barrier to integration rather than a facilitator (Voas \& Fleischmann, 2012; Foner \& Alba, 2008). In this respect, Moroccans may face discrimination due to their attachment to the Muslim religion, although they were among the first immigrants to arrive in the early 1970s. During the 2008 crises, it has been argued that Moroccan migrants felt anxious about losing their jobs due to their religious belonging, whereas the spreading of an Islamophobic climate in Italy constituted a push factor to return to their homeland (Sacchetto \& Vianello, 2016). Moroccans come from a society in which Islam is the dominant religion (Pew Research Center, 2011) and has a strong influence on people's everyday lives (Pruzan-Jorgensen, 2010). Prayer and attendance to the Mosque are the norm in Morocco, at least for men, whereas the religious role of the authoritarian regime (King and the ruling family) is indisputable. However, their

\footnotetext{
${ }^{1}$ This figure and the following ones derive from http://stra-dati.istat.it/ and refer to the $1^{\text {st }}$ January 2020.
} 
religious practice in Italy may be constrained as places of worship are limited and informal religious institutions are weak and managed by leaders that can exercise limited power (Ambrosini et al., 2020; Ricucci, 2017).

Religious institutions have traditionally had a marginal role for Albanian immigrants in Italy as well. Albanians come from a country with a Muslim majority, but also with a secular constitution characterised by religious pluralism (Endresen, 2012), with almost $27 \%$ of the population also being Christian. This is translated into tolerance towards religious freedom that is respected by the government. The principle of secularism is considered as a benchmark of the Albanian national identity ${ }^{2}$, for the sake of which religious differences are often downplayed. Nowadays, after over 25 years of immigration in Italy, Albanians are considered a well-integrated group with high numbers in naturalisations (Danaj \& Çaro, 2016; Dimitriadis, 2021). Yet, their integration path was not smooth in the first years, as the media and public discourse have reproduced stereotypes of Albanians being criminals and uncivilized that they tried to overcome through mimicry practices (King \& Mai, 2009). Evidence also suggests that Albanians were discriminated in the labour market in terms of both wages and access to qualified jobs (Mai \& Paladini, 2013).

Romanian immigrants experienced similar hurdles upon their arrival in the late 1990s and early 2000s: they faced the stigma of being low-skilled immigrants, while also being portrayed as criminals in the Italian political discourse and the media (Perrotta, 2011), thus resulting in harsh discrimination in the labour market and in the public sphere. Such social imaginaries might have been also due to the popular perception that Romanians belong to the Rom ethnic group (Ricucci, 2017). However, after Romania's adhesion to the EU in 2007, Romanians are EU citizens, and are considered as 'first class' immigrants. With regard to their religious associations, practicing Romanians could attend Russian and Greek Orthodox churches at the beginning of their migration experience, whereas the insertion of the Romanian Orthodox Church in the Italian landscape happened only quite recently. Romanian Church and State are strongly entangled as the church personnel is paid with public money, religion is a part of the school curricula and religious symbols are displayed in state institutions (Sandor \& Popescu, 2008). Moreover, especially after the fall of the communist regime, religiosity in Romania seems to also have experienced a small revival (Molteni, 2017), with the Romanian Church now considered a prime keeper of the national identity (Norris \& Inglehart, 2011).

\section{Theories on immigrant religiosity and intergenerational transmission}

This study draws on both sociology of religion and migration studies, thus taking into consideration various streams of theories that suggest increases or decreases in the religiosity of immigrants and their descendants. Quite differently from the contributions that analyse the positive role of religious institutions in the immediate followings of the migration processes (Hagan \& Ebaugh, 2003; Hirschman, 2004; Warner \& Wittner,

\footnotetext{
2 The most famous Albanian motto comes from a line of poetry by Pashko Vasa and claims "Mos shikoni kisha e xhamia / Feja e shqiptarit është shqiptaria" which basically means "And not look to church or mosque / The Albanian's faith is Albanianism [to be Albanian]".
} 
1998), the focus on religious transmission assumes instead a longer-term perspective. This is because we consider all the dynamics between parents and second-generation (and following) children which can create a strong and cohesive religious culture among the immigrant communities in the host societies.

Drawing from classic secularization theory (Berger, 1967; Bruce, 2002; Wilson, 1982), it is expected that higher levels of modernization in the receiving countries will reduce the salience of minorities' religious practice and belief, as they do for the majority. This mechanism is often advocated by scholars supporting assimilation theory (Alba \& Nee, 1997). Quite coherently, it is possible to derive the same expectation by looking at immigration studies, which predict that over time, and especially over generations, immigrants tend to be similar to members of receiving societies with regard to many aspects of behaviour and attitudes, including religion (Jacob \& Kalter, 2013; Alba \& Nee, 1997). If assimilation theory holds, immigrants' religiosity is expected to decrease over time as that of the natives. In fact, many studies have found such a decrease across generations (Connor, 2010; Güveli \& Platt, 2011; Phalet \& ter Wal, 2004; Smits et al., 2010), as well as over time (Diehl \& Schnell, 2006). In order to translate this reasoning into a hypothesis, we can say that:

\section{Hp. 1a: Religious transmission is weaker or similar among immigrants compared to native population}

The foregoing results are challenged by other contributions detecting a stability, or even an increase in immigrants' religious practices especially among Muslims (Güveli \& Platt, 2011; Phalet \& ter Wal, 2004; Smits et al., 2010; Maliepaard et al., 2012). Such empirical evidence is framed within the flipside of the assimilation theory that usually goes under the name of reactive ethnicity theory. This reaction is supposed to occur when immigrants experience discrimination and social exclusion in host societies and compensate by strengthening their ethnic and religious identities (Connor, 2010; Diehl \& Schnell, 2006; Portes \& Rumbaut, 2001). Parents who are weakly integrated tend, in fact, to put stronger effort in the intergenerational transmission of their culture in general, and of their religion in particular. If reactive ethnicity theory holds, an intergenerational increase - or at least a stability — of religiosity should be expected within the general immigrant population, and particularly within the most discriminated groups. Empirical confirmation of the saliency of reactive ethnicity theory is found in those contributions showing a stability or an increase of European Muslims' religiosity (Güveli \& Platt, 2011; Maliepaard et al., 2012; Smits et al., 2010; Phalet \& ter Wal, 2004; Soehl, 2017). Once again, this reasoning can be translated as a hypothesis alternative to H1a:

\section{Hp. 1b: Religious transmission is stronger among immigrants compared to native population}

While analysing the religious transmission occurring within immigrant families, one of the basic findings from Kelley and De Graaf (1997) comes to the aid. These scholars argue that parents put more effort in transmitting religion to their children in very secular settings or where their religion deviates in a certain way from that of the majority group. Translating this reasoning to immigrant's religiosity, it is possible to 
hypothesize that the religious transmission within immigrant families will be stronger because of their minority status. In fact, many scholars have underlined this first generation's desire to transmit all the religious values from their country of origin to their children (Ebaugh \& Chafetz, 2000). Strongly opposed to this line of reasoning, Kuszynski et al. (1997) argue that immigrant parents may try to help their children to adapt in the receiving societies by encouraging them to hold different values than their own. This will result in the choice to raise the children with less strict religious values or to allow them to be less religious (De Hoon \& van Tubergen, 2014).

These two opposed mechanisms became more salient while explicitly focusing on Muslim immigrants. If the first line of reasoning is true (parents from a minority put more effort in transmitting their religiosity to the children), the transmission rates among Muslims are supposed to be higher than the non-Muslim immigrant ones. This is because Muslim migration also involves a change from a religious majority to a religious minority status (Yang \& Ebaugh, 2001), which, in turn, forces immigrant parents to invest more in the religious upbringing of their children. Moreover, with the benefits of education, idealism and individualism that Western hosting societies provide (Voas \& Fleischmann, 2012), some second-generation Muslims can also look for what can be intended as a "real Islam", which partially takes the distance from the defects they see in their parental culture. Following the second line of reasoning, instead, the relatively strong anti-Muslim sentiment in Europe might discourage Muslim parents from transmitting their religion to their children in order to help them to integrate. Again, this reasoning can be posed in the form of two alternative hypotheses:

Hp. 2a: Religious transmission in Italy is stronger among Muslim immigrants compared to Christian immigrants

Hp. 2b: Religious transmission in Italy is weaker among Muslim immigrants compared to Christian immigrants

In addition to the assimilation pressures or the potential reaction, immigrants' religiosity can also be affected by "practical" hindrances that can disrupt religious practice. This can seriously limit religious practice especially among Muslims in Europe (Smits et al., 2010), as religious practice and participation are often a matter of routine; migration may not change beliefs, but will almost undoubtedly alter old habits (Wuthnow \& Christiano, 1979). This, together with the different visibility of public practice and private beliefs and the different meanings the different religious traditions attach to practice, brings us to widen the notion of religiosity and stress its multidimensional nature. As a matter of fact, the broad concept of religiosity is made by a mixture of supernatural, practical, ritual, and normative aspects which are closely interrelated (Molteni \& Biolcati, 2018). Given the presence of both Muslim and Christian immigrants, it therefore becomes essential to distinguish between the transmission of public attendance (which is more visible and more accessible for Christian immigrants) and private religiosity (less visible and less based on practical resources), also because different religious traditions may attach different meanings to different dimensions.

Hp. 3a: The transmission of public attendance is stronger among Christian immigrants compared to Muslim immigrants 
Hp. 3b: The transmission of private religiosity is stronger among Muslim immigrants compared to Christian immigrants

In the light of the foregoing theoretical considerations and contextual information in the previous section, we now present the data and methodology of this paper, and then analysis and discussion follow.

\section{Data, variables and methods}

\section{Dataset and sample}

The empirical study of immigrants' religiosity in Italy has been quite underdeveloped, mainly due to the lack of high-quality data (Panichella \& Cantalini, 2018). This changed to some extent since the "Social conditions and integration of foreign citizens" survey was carried out by ISTAT in 2011-2012. The aim of this survey is to gather information about various aspects of immigrants' life including family composition, education, religiosity, work conditions, migratory background, health situation, social relations and many others. Overall almost 25,326 individuals from 12,000 households with at least one foreign member have been interviewed. The population to be sampled was identified based on the citizenship criteria and the selection of the interviewees occurred through a two-stage design (municipalities and families). Municipalities were selected by region and by a probability proportional to the number of foreign residents. Being household based, this survey allows us to study the parents-children dyads for what concerns religiosity and religious transmission.

From the overall sample, we have selected a subsample of couples with children (at least 15 years old ${ }^{3}$ ) in which at least one parent is foreign-born. Being Romanians, Albanians and Moroccans, the three biggest immigrant groups in Italy, the choice is to restrict the analysis to them (for additional information about how we select them, see the next paragraph). From the theoretical and empirical point of view, this has a clear implication: we are focusing on one Christian group (Romanians), one Muslim group (Moroccans) and one mixed group (Albanians). For the purposes of this research, the choice was to distinguish between Albanian Christians and Albanian Muslims.

The main shortcoming of this dataset is that it does not have data for the native population. In order to - partially - provide them, we have supplemented this dataset with the "AVQ (daily life aspects)" 2013 dataset. This survey is also carried out by ISTAT and shares with the "Social condition and integration of foreign citizens" survey the same research design, as well as many of the questions. Unfortunately, this survey contains only the question about service attendance. With respect also to the native population, we are using a subsample of couples with children aged 14 or more. The information about the sample we used, as well as some salient characteristics, are reported in Table 1.

\footnotetext{
${ }^{3}$ The choice of this threshold is because of the need to exclude very young children who just replicate parents' religiosity.
} 
Table 1 Characteristics of the sample

\begin{tabular}{lccc}
\hline & $\begin{array}{l}\mathrm{N} \\
\text { (individuals) }\end{array}$ & $\begin{array}{l}\mathrm{N} \\
\text { (households) }\end{array}$ & $\begin{array}{l}\text { Year of migration } \\
\text { (average) }\end{array}$ \\
\hline Italian natives & 9219 & 3135 & $n / a$ \\
Romanians & 1834 & 855 & 2003 \\
Albanian Christians & 969 & 458 & 2000 \\
Albanian Muslims & 645 & 324 & 2001 \\
Moroccans & 1026 & 435 & 1999 \\
Total & 13,693 & 5077 & $n / a$ \\
\hline
\end{tabular}

\section{Variables}

Given the strongly multidimensional nature of this work, we present three different dependent variables.

The measure for religious practice comes from an item asking: "How often do you usually go to the Church or to another place of worship?" We transformed the categorical variable into a numerical one measuring the average probability of attending church or another place of worship daily. In doing so, we assigned, for example, a value of 0.99 to those who declare that they attend church or other places of worship daily (365 days over 365 days in a year), a value of 0.14 to those who attend weekly ( 52 days over 365 days in a year) and a value of 0.00 to those who never attend (Hout \& Greeley, 1998).

The second dimension we want to inspect is that of religious prayer. We started from the item "How often do you pray or declaim sacred formula outside religious services?", and we apply the same strategy that we used for service attendance. We thus operationalize it as the daily probability of praying.

The third dimension we want to introduce is that of religious importance. Compared to religious practice and prayer, this dimension suffers less from the potential different meanings attached by different religious traditions and is therefore more suitable for a multi-group comparison. Its operationalization is quite straightforward. We started from the item "How important is religion in your life?", and we kept the original format which is a scale ranging from 0 ("not important at all") to 10 ("very important"). Just to have the same range as the other two variables, we have rescaled it to range from 0 to 1 .

Starting from these three variables, we calculated the difference between the religiosity of the most religious parent and the religiosity of the children. These variables, which represent the intergenerational change in religiosity for each of the three dimensions, will be the dependent variables of the parametric models: positive values mean losses in religiosity while negative values mean gains in religiosity.

In addition to the dependent variables, we used the country of origin of the parents as the main independent variable. This information comes directly from the general section of the questionnaire under the entry "Foreign country of birth". In order to select the sample, we used the father's country of birth and, if the father is Italian, the one of the mother ${ }^{4}$.

\footnotetext{
${ }^{4}$ This operation is possible because the number of mixed-marriages between individuals coming from different foreign countries is negligible (less than $1 \%$ ).
} 
In the regression models, we also use some control variables to account for possible spurious effects. These variables are age (12 categories, treated as linear because of the same size of the categories), sex (dichotomized as "female"), education (5 categories) and two dichotomous variables measuring if the individual was born in Italy or abroad, or if both parents belong to the same religious denomination (Jacob, 2020).

\section{Methods}

As argued in the theoretical section, the focus on religious transmission adopts a longer-term perspective if compared to the study of religious evolution in the immediate followings of the migration processes. In order to fully account for this, this research is carried out in two different stages. The first one is descriptive and is based on a comparison of the averages of the different dimensions of religiosity by country of origin and family role. The second stage, instead, is based on sets of regressions which investigate the impact of the main independent variable (country of origin of the parents) on the three dependent variables: the intergenerational change of religious service attendance, prayer, and the importance of religion ${ }^{5}$. In addition, five control variables (age, gender, education, and the dichotomies born/ not born abroad and religiously homogeneous/not homogeneous parents) are used. To avoid the strong bias related to the different levels of religiosity of the different groups (Moroccans, for example, are far more religious than Romanians), we adopted the strategy of comparing "similar" parents (De Hoon \& van Tubergen, 2014). We did so by identifying three groups of parents based on the answers they gave to the questions related to the three dependent variables, and then running separate sets of regressions for each of the three groups. The way in which we identified these groups is presented in Table 2.

\section{Results}

The descriptive part of the results is reported in Table 3. What emerges is that Moroccans and Albanian Muslims are by far the most religious groups. They practice more, pray more, and give the highest importance to religion both compared to other immigrant groups and the native population. This is far from unexpected because of the strong emphasis that Muslim religion puts on service attendance. Romanians and Christian Albanians immigrants, instead, show values of religious practice more similar to the native population.

Another important indication that we can draw from these data regards the gender differences in religiosity. As for the native population and the Romanian and Albanian immigrant groups, religiosity is higher among mothers than among fathers in all the three dimensions. This confirms the well-known finding in the literature of women being more religious (de Vaus \& Mcallister, 1987; Ida \& Saud, 2020). For what concerns Moroccans, the situation is different. Figures for prayer are still slightly higher for women, but practice and religious importance

\footnotetext{
${ }^{5}$ Analysis has been carried on using Stata 16.1 MP and basic regression commands.
} 
Table 2 Criteria for grouping the parents

\begin{tabular}{llll}
\hline & Attendance & Prayer & Importance \\
\hline Secular parents & No & No & $0-3$ \\
Moderate religious parents & Monthly-yearly & Weekly-yearly & $4-9$ \\
Highly religious parents & Weekly-daily & Daily & 10 \\
\hline
\end{tabular}

are higher for men. This also confirms the theoretical expectation which sees Islam in general — and Mosque attendance in particular - as a mainly male activity.

Looking at the descriptive results, the need to distinguish between groups of parents according to their religiosity appears evident. This is because the tendency to transmit religiosity can be very different according to the starting level. If, for example, a parent prays daily, the religiosity of his/her children can only decrease or be the same. On the contrary, parents who pray only yearly can also have children who pray more frequently.

This translates in a set of regressions in which the units of analysis are children who are 14 years old or more. Due to the lack of information about prayer and importance of religion for the native population, we firstly present the results for religious service attendance in which we include also the natives, and secondly the results for service attendance, prayer and importance of religion that, however, exclude the native population.

\section{Religious transmission among migrant groups and natives}

In order to make the reading of the results smoother, we here recall that the three dependent variables measure the differences in religiosity between parents and children.

Table 3 Descriptive results

\begin{tabular}{|c|c|c|c|c|c|c|c|}
\hline & & Romanian & Albanian C. & Albanian M. & Moroccan & Natives & Total \\
\hline \multirow[t]{3}{*}{ Husband } & Daily attendance & 0.06 & 0.05 & 0.05 & 0.19 & 0.08 & 0.07 \\
\hline & Daily pray & 0.21 & 0.24 & 0.76 & 0.43 & l & 0.39 \\
\hline & Importance & 0.70 & 0.61 & 0.89 & 0.85 & I & 0.74 \\
\hline \multirow[t]{3}{*}{ Spouse } & Daily attendance & 0.09 & 0.07 & 0.06 & 0.14 & 0.10 & 0.11 \\
\hline & Daily pray & 0.33 & 0.28 & 0.80 & 0.50 & / & 0.49 \\
\hline & Importance & 0.77 & 0.64 & 0.91 & 0.80 & l & 0.80 \\
\hline \multirow[t]{3}{*}{ Children } & Daily attendance & 0.06 & 0.06 & 0.05 & 0.13 & 0.07 & 0.06 \\
\hline & Daily pray & 0.22 & 0.17 & 0.61 & 0.33 & I & 0.29 \\
\hline & Importance & 0.67 & 0.57 & 0.82 & 0.70 & l & 0.69 \\
\hline \multirow[t]{3}{*}{ Total } & Daily attendance & 0.07 & 0.06 & 0.06 & 0.16 & 0.08 & 0.08 \\
\hline & Daily pray & 0.26 & 0.24 & 0.75 & 0.44 & I & 0.42 \\
\hline & Importance & 0.72 & 0.61 & 0.88 & 0.76 & l & 0.76 \\
\hline
\end{tabular}


From this derive that negative coefficients mean effective religious transmission (children are more religious than parents) while positive coefficients mean weaker religious transmission (higher "loss" in religiosity from parents to children).

The results for service attendance (Table 4, natives included) show some relevant differences between the three groups of parents. In fact, immigrant secular parents seem to be more successful (negative coefficients) than natives in transmitting their religiosity to their children, and this holds for all the four groups. Clearly, this reflects the fact that children of very secular parents do not have room for further decreases. For what concerns moderately religious families instead, we do not see neither huge losses nor gains, and we do not see differences among the different groups and between the different groups and the native population. The situation for highly religious parents, instead, is very different. There is a general intergenerational loss of religiosity of 4 points which affects the natives, the Romanians and the Albanian Christians (their coefficients being not statistically significant). Starting from this 4 points loss, Moroccans and Albanian Muslims lose another 19 and 18 points respectively, which results in a very poor transmission of service attendance for highly religious Muslim parents. This can reflect both the stigma associated with Muslim public practice and the lack of places of worship. These results go in the direction of confirming hypothesis Hpla (Religious transmission is weaker or similar among immigrants compared to native population). However, these findings only apply to service attendance. It is only by looking at the other dimensions and at the differences between immigrant groups that this study can really push forward the understanding of the patterns of religious transmission.

Looking at the control variables, it is worth stressing that the transmission of service attendance works slightly better for females (smaller losses) and that is not affected by the other variables (except for being born abroad from very secular parents).

Table 4 Regression models for service attendance (Italian natives included)

\begin{tabular}{lccc}
\hline Service attendance & Secular & Moderate & Highly \\
\hline Romanian (ref: Italian natives) & $-0.07^{* *}$ & $-0.05^{*}$ & 0.10 \\
Albania Christians (ref: Italian natives) & $-0.08^{* * *}$ & -0.03 & -0.02 \\
Albania Muslims (ref: Italian natives) & $-0.07^{* *}$ & -0.02 & $0.18^{* *}$ \\
Moroccan (ref: Italian natives) & $-0.05^{*}$ & -0.01 & $0.19^{* * *}$ \\
Age & 0.00 & $0.00^{*}$ & 0.01 \\
Female & -0.00 & $-0.02^{* * *}$ & $-0.04^{* * *}$ \\
Born Abroad & $0.09^{* * *}$ & 0.03 & -0.05 \\
Primary (ref: No Edu) & -0.02 & -0.02 & 0.05 \\
Lower Secondary (ref: No Edu) & -0.02 & -0.01 & 0.09 \\
Upper Secondary (ref: No Edu) & -0.02 & 0.00 & 0.12 \\
Tertiary (ref: No Edu) & -0.01 & -0.01 & 0.14 \\
Parents same religion & 0.01 & $-0.02 *$ & -0.00 \\
Constant & -0.03 & 0.02 & 0.04 \\
N & 396 & 1785 & 1385 \\
\hline
\end{tabular}

$* * * p<0.01, * * p<0.05, * p<0.1$

Negative values mean lower losses of religiosity, namely more effective religious transmission 


\section{The intergenerational transmission of religiosity among migrant groups}

We now move to the models regarding service attendance, prayer and importance of religion that compare only the immigrant groups (Table 5). The reference category will be the Romanians because they appear to be the most similar group if compared to the natives. They share the Christian denomination, similar levels of religiosity (see also Table 3 ) and the belonging to the European Union. Given that we have rather small numerosity here, it turns out that the tests based on statistical significance are very conservative. Therefore, we decided to accept and interpret also coefficients which stand in the $90 \%$ confidence level.

The reading of this table is quite simple. There are no big differences between the immigrant groups except for the Moroccan. In fact, among Moroccans, we find a very poor transmission of public practice (who lose 9 more points among highly religious families), but also a better transmission of both praying behaviour (18- and 17-point gains for secular and highly religious families respectively) and the importance attached to religion (8-point gain for highly religious families). Albanian Muslims, instead, seem to replicate the Moroccans' poor transmission of service attendance (additional 8-point loss, albeit not statistically significant), but they turn out to be much similar to Romanians and Albanian Christians on the other dimensions (even though they also report a poorer transmission of praying behaviour). Notably, variables that usually have a strong impact on religiosity, such as education and even gender, show negligible effects when looking at transmission between immigrants. This reinforces the role of the interplay between origin and destination characteristics as the main driver of religious transmission.

Table 5 Regression models for service attendance, pray and religious importance (Italian natives excluded)

\begin{tabular}{|c|c|c|c|c|c|c|c|c|c|}
\hline & \multicolumn{3}{|c|}{ Attendance } & \multicolumn{3}{|l|}{ Pray } & \multicolumn{3}{|c|}{ Importance } \\
\hline & Secular & Moderate & Highly & Secular & Moderate & Highly & Secular & Moderate & Highly \\
\hline $\begin{array}{l}\text { Albanian Christian } \\
\text { (ref: Romanian) }\end{array}$ & -0.01 & 0.02 & -0.10 & -0.05 & -0.00 & 0.05 & -0.11 & $-0.04 *$ & 0.03 \\
\hline $\begin{array}{l}\text { Albanian Muslim } \\
\text { (ref: Romanian) }\end{array}$ & -0.00 & 0.02 & 0.08 & 0.01 & 0.03 & $0.14 *$ & -0.14 & $0.04 *$ & -0.01 \\
\hline $\begin{array}{l}\text { Moroccan } \\
\quad \text { (ref: Romanian) }\end{array}$ & 0.02 & 0.03 & $0.09 *$ & $-0.18 * * *$ & 0.01 & $-0.17 * * *$ & I & -0.04 & $-0.08 * *$ \\
\hline Age & 0.00 & -0.01 & 0.02 & -0.01 & 0.02 & 0.01 & -0.11 & $0.03 * *$ & 0.01 \\
\hline Female & 0.00 & -0.01 & $-0.09^{* *}$ & -0.00 & $-0.08 * *$ & -0.05 & $-0.27 *$ & -0.00 & -0.03 \\
\hline Born abroad & $0.08 * * *$ & 0.04 & -0.08 & $0.15 * *$ & 0.11 & -0.06 & 0.42 & 0.02 & -0.02 \\
\hline Primary (ref: No Edu) & -0.04 & -0.04 & -0.11 & -0.15 & -0.16 & 0.35 & / & 0.01 & -0.22 \\
\hline $\begin{array}{l}\text { Lower secondary } \\
\quad(\text { ref: No Edu) }\end{array}$ & -0.02 & 0.00 & -0.11 & -0.03 & 0.06 & $0.37 *$ & -0.01 & 0.08 & -0.22 \\
\hline $\begin{array}{l}\text { Upper secondary } \\
\text { (ref: No Edu) }\end{array}$ & -0.02 & 0.01 & -0.10 & -0.01 & 0.06 & $0.38^{*}$ & -0.24 & 0.07 & -0.21 \\
\hline Tertiary (ref: No Edu) & -0.01 & 0.02 & 0.14 & -0.00 & 0.05 & 0.46 & 0.55 & 0.03 & -0.25 \\
\hline Parents same religion & 0.01 & -0.02 & 0.01 & -0.02 & -0.05 & -0.06 & 0.23 & 0.02 & $-0.06 * *$ \\
\hline Constant & $-0.10 * *$ & 0.01 & 0.29 & -0.08 & -0.11 & 0.19 & 0.13 & -0.12 & $0.45^{* *}$ \\
\hline $\mathrm{n}$ & 191 & 283 & 241 & 135 & 230 & 334 & 21 & 345 & 267 \\
\hline
\end{tabular}

$* * * p<0.01, * * p<0.05, * p<0.1$

Negative values mean lower losses of religiosity, namely more effective religious transmission 
Not surprisingly, the highly religious groups of parents turn out to be the ones providing the most interesting findings: Fig. 1 reports a visual summary of their coefficients. For what concerns the transmission of service attendance, the disadvantage of being Muslim is clear especially when looking at Moroccans, which is the group performing worst. As for the more private dimensions of prayer and religious importance, we see Albanian Muslims to be similar to the other Christian groups, whereas Moroccans to be the most effective in transmitting their religiosity. Albanian Christians and Romanians stand somewhere in the middle. These findings clearly suggest that Moroccan parents are quite successful in transmitting Muslim religiosity to their children, over and above the practical limitations linked to Mosque attendance.

When recalling the hypotheses introduced in the theoretical section, these results permit to generally confirm hypothesis 2a (Religious transmission in Italy is stronger among Muslim immigrants compared to Christian immigrants). Within this general reading, it is also relevant to note that the transmission of public attendance is stronger among Christian immigrants (Hp3a confirmed) and also that the transmission of private religiosity is stronger among Muslim immigrants (Hp3b confirmed).

\section{Discussion}

In this paper, we studied the intergenerational transmission of religious behaviour and religiosity among immigrants in a Southern European country, Italy. As far as we know, this is the first work within this region. On the one hand, it is argued that the specificities of Italy as a receiving society characterized by religious homogeneity may shape the patterns of intergenerational religious transmission. On the other hand, country of origin influences as well as differences in the societal role of religion may lie behind variations the in transmission of religiosity among different immigrant groups.

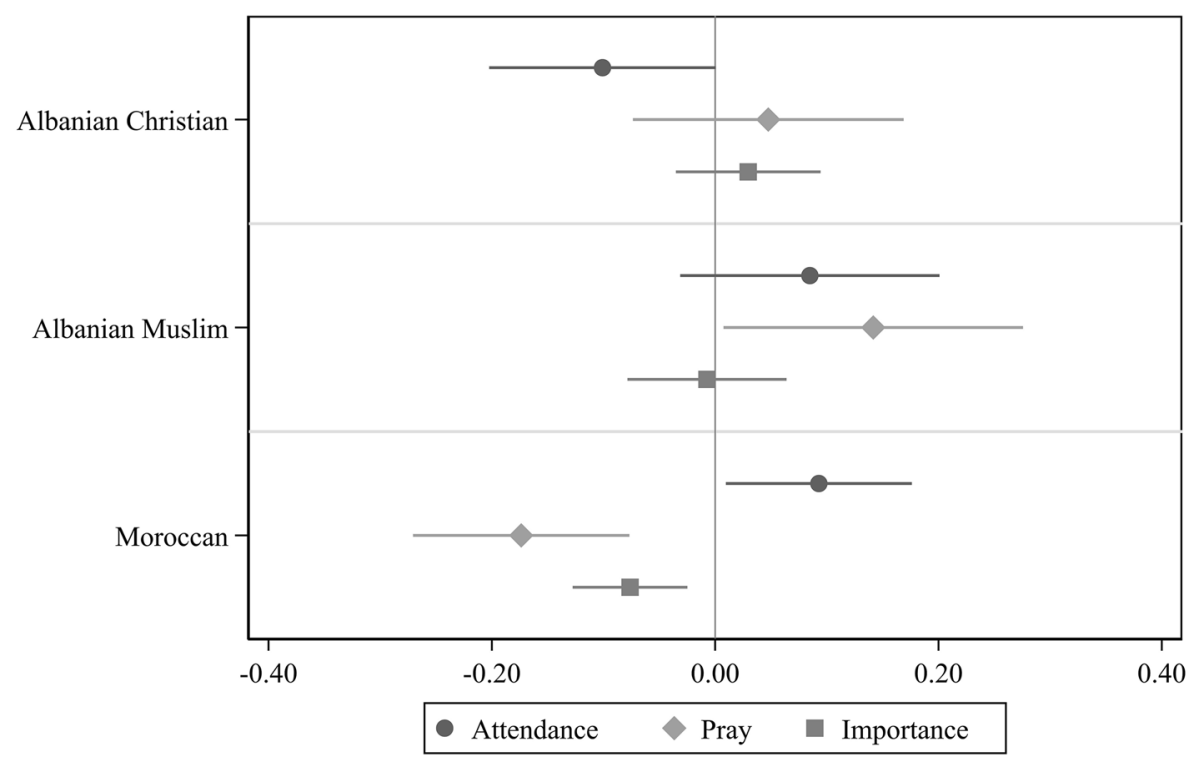

Fig. 1 Plot of coefficients for highly religious parents (ref: Romanian) (90\% C.I.) 
What really turn out to be of interest in our analysis are the differences in intergenerational transmission within the most religious families of the three immigrant groups. Starting from the public dimension, Albanian Christians are those who transmit religious practice more successfully, and the Romanians follow. This may be interpreted by the fact that these immigrant groups share the same religion with the majority, so their practice cannot be an obstacle for integration. The difference between Albanian Christians and Romanians may be attributed to the fact that the majority of the former are Catholics, and therefore they share the same doctrine of natives. As regards the Muslim groups of our sample, Moroccans and Albanians perform worse than other groups in transmitting their public practice. There are two main reasons that can explain this result. First, their religion is under scrutiny in Western Society (De Hoon \& van Tubergen, 2014; Ricucci, 2017), and thus they try to facilitate their children's integration by not insisting on mosque attendance. In other words, parents may decide not to pursue the transmission of public practice, as this can be the cause of direct experiences of discrimination (for instance, problems when praying at workplace) or perceived discrimination within the Italian society. Second, Muslim religious meeting places in Italy are limited, which can constrain immigrants' religious practice ${ }^{6}$.

As far as the comparisons between immigrant populations and natives is concerned, it can be claimed that the patterns of religious transmission of Christian migrants are similar to Italians', whereas immigrant Muslims are less successful in transmitting religious practice to their children, thus confirming again discrimination of Islam in Western societies. However, the comparison between natives and immigrants remains partly uncompleted due to the lack of data on the importance of religion and praying among Italians.

Moving to the more private dimensions of religiosity and comparing the three immigrant groups, Moroccans transmit the importance of religion and praying behaviour to their children in a very efficient way. In line with other research performed in different countries (van Tubergen \& Sindradóttir, 2011; De Hoon \& van Tubergen, 2014), this indicates that Muslim immigrant groups are more successful compared to Christians, since the Islamic religion is a minority religion in Italy, and these groups may put more effort in transmitting religious values to their children (Kelley \& De Graaf, 1997). This trend among Moroccans may be attributed to the effects of both countries of origin and destination. On the one hand, first-generation immigrants come from a very religious country where the attachment to Islamic values and practices (e.g. praying, fasting, abstinence from alcohol) is very high (Maliepaard et al., 2012), as well as their feelings of identification with Morocco (Beek \& Fleischmann, 2020). On the other hand, they feel that their identities are under threat in Italy due to the discrimination they perceive. Therefore, the tendency is to react by putting emphasis on the transmission of at least the private - and less visible - dimensions of religiosity. On the contrary, the performance of Albanian Muslims concerning this dimension is far less efficient than that of Moroccans. This may be explained by the differences in religious traditions in the origin countries, as well as the competition with their national counterparts. In other words, Albanian Muslims do not only have the disadvantage of being discriminated due to their faith, but also of being a stigmatized part of their own community. Once again, not transmitting religiosity to their offspring might be seen as a way to protect their children

\footnotetext{
${ }^{6}$ According to Cuciniello (2017), there were about 858 praying places in 2016, but only six of them are proper mosques. The extreme majority regards informal praying rooms or spaces (mușallā).
} 
from direct or perceived discrimination within the host society. In addition, it can be argued that Albanian Muslims have grown in a secular country, without any official religion. Therefore, Albanian Muslims might put less effort in transmitting religiosity to their children with respect to Moroccans also because of the differences in religious traditions in the country of origin, thus confirming that such traditions are able to orient behaviours (Peach \& Gale, 2003). Shortly said, secularization of Albanian Muslims is proceeding with a fast rate, and this recalls the situation of the context of origin.

Going back to the dichotomy between assimilation and reactive ethnicity theory, our results suggest that the situation for Romanians and Albanians fall under the umbrella of assimilation theory, whereas the reading for Moroccans is compatible with reactive ethnicity theory. Within this general reading, this article makes a further theoretical contribution by analysing the interplay between origin and destination countries. Indeed, as far as Italy is concerned, an almost religiously homogeneous Christian country, our findings indicate that for immigrants coming from a country sharing similar characteristics (Romania), a strong assimilation pressure emerges. At the same time, immigrants coming from a very secular country such as Albania tend to follow the religious patterns that are present in the country of origin. This implicates very few differences between individual denominations, with both Christians and Muslims' secularization proceeding at a fast pace. On the contrary, immigrants coming from a country with a totally different religious background (Morocco, homogeneously Muslim) are observed to react by strengthening and transmitting their religious identities.

We mentioned in the theoretical section that Italy shares many common characteristics with other Southern European countries, and this led many scholars to refer to a "Southern European model of immigration" which applies to Italy, Spain, Greece and Portugal (King, 2000; Fellini, 2018). Although recognizing the existence of country specificities in relation to historical paths and socio-economic situations (Peixoto et al., 2012), our findings may pave the way and serve as a basis for further analyses in such countries. Being Romanians and Moroccans, the two most numerous immigrant groups in Spain (an almost homogeneously Christian Catholic country), and being Albanians, the biggest group in Greece (an almost homogeneously Christian Orthodox country), it can be argued that immigrants in these countries might show patterns of intergenerational transmission of religiosity that are similar to their counterparts in Italy. In addition, our results are likely to be also important for Portugal (a homogeneously Christian Catholic country) where the main immigrant groups are mainly Christian. This is because, as we have demonstrated, the interplay between these characteristics is what mainly shapes the dynamics of religious transmission.

In light of the results of this article and taking into consideration the rising hostility of European societies towards migrants, we may suppose that religious transmission to second generations is increasingly becoming a central issue for immigrant parents and that this is particularly salient for Muslim groups. Indeed, they are expected to insist less in transmitting at least public dimensions of religiosity in order to facilitate their children's integration, making them less exposed to discrimination and xenophobia. This may regard both real discrimination (e.g. limited opportunities in the labour market) and perceived discrimination, that is, feelings of being excluded from the host society. Last but not the least, this trend might be of great relevance within Southern European countries where migratory inflows have increased in the last decade and are characterised by heterogeneity in terms of country origin and religion (increase of Muslim migrants). Therefore, new arrivals are considered to 
reinforce not only economic concerns (e.g. risk of unemployment) that can condition Southern Europeans' hostility towards migrants, but also cultural concerns that are often expresses in terms of religious tradition. Perceived incompatibility of norms and values between majority and minority (Muslim) groups may thus generate further hostility towards Muslims in Southern Europe.

\section{Conclusions and final remarks}

This article represents the first attempt to study religious transmission in Italy by referring to data specifically targeted to study the immigrant population. The structure of the data comes with at least two very relevant advantages and one big limit. The two major advantages are the possibility to compare parents and children from the same families and the possibility to adopt a strongly multidimensional definition of religiosity. This second point turned out to be very relevant given the different results that emerged for public and private religiosity. The main limit is instead the impossibility to compare immigrant groups and the native population. We partially overcome such limit by supplementing the data with another comparable source, but such comparison remains partly uncompleted due to the lack of data on the importance of religion and praying among Italians.

Starting from this limit, further research becomes necessary to comprehend better the patterns of integration and secularization of immigrant groups in Southern European countries, which are characterized by levels of religiosity that are far different from Nordic or Central European countries. In doing this, the comparison with the native populations is essential. Moreover, further aspects that could be fruitfully investigated include identity issues (Ricucci, 2017), social cohesion (Maliepaard \& Lubbers, 2013), peer effects (De Hoon \& van Tubergen, 2014) and parental background in order to provide more insights about the determinants of religious transmission which lie behind group membership.

Funding Open access funding provided by Università degli Studi di Milano within the CRUI-CARE Agreement.

Open Access This article is licensed under a Creative Commons Attribution 4.0 International License, which permits use, sharing, adaptation, distribution and reproduction in any medium or format, as long as you give appropriate credit to the original author(s) and the source, provide a link to the Creative Commons licence, and indicate if changes were made. The images or other third party material in this article are included in the article's Creative Commons licence, unless indicated otherwise in a credit line to the material. If material is not included in the article's Creative Commons licence and your intended use is not permitted by statutory regulation or exceeds the permitted use, you will need to obtain permission directly from the copyright holder. To view a copy of this licence, visit http://creativecommons.org/licenses/by/4.0/.

\section{References}

Alba, R., \& Nee, V. (1997). Rethinking assimilation theory for a new era of immigration. The International Migration Review, 31(4), 826-874.

Ambrosini, M. (2013). Immigration in Italy: Between economic acceptance and political rejection. Journal of International Migration and Integration, 14(1), 175-194. 
Ambrosini, M. (2018). Irregular Immigration in Southern Europe. Palgrave Macmillan.

Ambrosini, M., Bonizzoni, P., \& Molli, S. D. (2020). How religion shapes immigrants' integration: The case of Christian migrant churches in Italy. Current Sociology, 00(0), 1-20 Online first.

Beek, M., \& Fleischmann, F. (2020). Religion and integration: Does immigrant generation matter? The case of Moroccan and Turkish immigrants in the Netherlands. Journal of Ethnic and Migration Studies, 46(17), 3655-3676.

Berger, P. (1967). The Sacred Canopy. Anchor Books.

Bonizzoni, P. (2018). Looking for the best and brightest? Deservingness regimes in Italian labour migration management. International Migration, 56(4), 47-62.

Bruce, S. (2002). God is dead: Secularization in the West. Blackwell.

Buijs, F. J., \& Rath, J. (2006). Muslims in Europe: The state of research. In IMISCOE Working Paper.

Cesareo, V., Cipriani, R., Garelli, F., Lanzetti, C., \& Rovati, G. (1995). La religiosità in Italia [Religiosity in Italy]. Milano: Arnoldo Mondadori Editore.

Cesari, J. (2003). Muslim minorities in Europe: The silent revolution. In J. Esposito \& F. Burgat (Eds.), Modernizing Islam: Religion in the Public Sphere in the Middle East and in Europe (pp. 251-269). Rutgers University Press.

Connor, P. (2010). Contexts of immigrant receptivity and immigrant religious outcomes: The case of Muslims in Western Europe. Ethnic and Racial Studies, 33(3), 376-403.

Cuciniello, A. (2017). Luoghi di culto islamici in Italia: tipologie e dati. Paper ISMU. https://www.ismu.org/ wp-content/uploads/2020/08/Cuciniello_Luoghi_di_culto_islamici_in_Italia.pdf

Danaj, S., \& Çaro, E. (2016). Becoming an EU citizen through Italy: The experience of Albanian immigrants. Mondi Migranti, 3, 95-108.

De Hoon, S., \& van Tubergen, F. (2014). The religiosity of children of immigrants and natives in England, Germany, and the Netherlands: The role of parents and peers in class. European Sociological Review, 30(2), 194-206.

de Vaus, D., \& Mcallister, I. (1987). Gender differences in religion: A test of the structural location theory. American Sociological Review, 52(4), 472-481.

Diehl, C., \& Schnell, R. (2006). 'Reactive ethnicity'or 'assimilation'? Statements, arguments, and first empirical evidence for labor migrants in Germany. International Migration Review, 40(4), 786-816.

Dimitriadis, I. (2021). Onward migration aspirations and transnational practices of migrant construction workers amidst economic crisis: exploring new opportunities and facing barriers. International Migration, 00, 1-14 (Early View)

Ebaugh, H. R., \& Chafetz, J. S. (2000). Religion and the new immigrants: Continuities and adaptations in immigrant congregations. AltaMira Press.

Endresen, C. (2012). Is the Albanian's religion really "Albanianism”? Religion and nation according to Muslim and Christian leaders in Albania. Harrassowitz.

Fellini, I. (2018). Immigrants' labour market outcomes in Italy and Spain: Has the Southern European model disrupted during the crisis? Migration Studies, 6(1), 53-78.

Fellini, I., \& Guetto, R. (2019). A U-shaped pattern of immigrants' occupational careers? A comparative analysis of Italy, Spain, and France. International Migration Review, 53(1), 26-58.

Fleischmann, F., \& Phalet, K. (2012). Integration and religiosity among the Turkish second generation in Europe: A comparative analysis across four capital cities. Ethnic and Racial Studies, 35(2), 320-341.

Foner, N., \& Alba, R. (2008). Immigrant religion in the U.S. and Western Europe: Bridge or barrier to inclusion? International Migration Review, 42(2), 360-392.

Fullin, G. (2016). Labour market outcomes of immigrants in a South European country: Do race and religion matter? Work. Employment and Society, 30(3), 391-409.

Fullin, G., \& Reyneri, E. (2011). Low unemployment and bad jobs for new immigrants in Italy. International Migration, 49, 118-147.

Garelli, F. (1991). Religione e chiesa in Italia [Religion and church in Italy]. Il Mulino.

Glass, J., Bengtson, V. L., \& Chorn Dunham, C. (1986). Attitude similarity in three-generation families : Socialization, status inheritance, or reciprocal influence ? American Sociological Review, 51(5), 685-698.

Guetto, R., \& Fellini, I. (2017). Immigrant women's employment patterns: Disentangling the effects of ethnic origin, religious affiliation and religiosity. Rassegna Italiana di Sociologia, 58(4).

Güngör, D., Bornstein, M. H., \& Phalet, K. (2012). Religiosity, values, and acculturation: A study of Turkish, Turkish-Belgian, and Belgian adolescents. International Journal of Behavioral Development, 36(5), 367373.

Güveli, A., \& Platt, L. (2011). Understanding the religious behaviour of Muslims in the Netherlands and the UK. Sociology, 45(6), 1008-1027. 
Hagan, J., \& Ebaugh, H. R. (2003). Calling upon the sacred: Migrants' use of religion in the migration process. International Migration Review, 37(4), 1145-1162.

Hirschman, C. (2004). The role of religion in the origins and adaptation of immigrant groups in the United States. International Migration Review, 38(3), 1206-1233.

Hout, M., \& Greeley, A. M. (1998). What church officials' reports don't show: Another look at church attendance data. American Sociological Review, 63, 113-119.

Ida, R., \& Saud, M. (2020). The narratives of Shia Madurese displaced women on their religious identity and gender citizenship: A study of women and Shi'as in Indonesia. Journal of Religion and Health Online First.

Jacob, K. (2020). Intergenerational transmission in religiosity in immigrant and native families: The role of transmission opportunities and perceived transmission benefits. Journal of Ethnic and Migration Studies, 46(9), 1921-1940.

Jacob, K., \& Kalter, F. (2013). Intergenerational change in religious salience among immigrant families in four European countries. International Migration, 51(3), 38-56.

Kelley, J., \& De Graaf, N. D. (1997). National context, parental socialization, and religious belief: Results from 15 nations. American Sociological Review, 62(4), 639-659.

King, R. (2000). Southern Europe in the changing global map of migration. In R. King, G. Lazaridis, \& C. Tsardanidis (Eds.), Eldorado or fortress? Migration in Southern Europe. Macmillan.

King, R., \& Mai, N. (2009). Italophilia meets Albanophobia: Paradoxes of asymmetric assimilation and identity processes among Albanian immigrants in Italy. Ethnic and Racial Studies, 32(1), 117-138.

Kuszynski, L., Marshall, S., \& Schell, K. (1997). Value socialization in a bidirectional context. In E. Grusec \& L. Kuczynski (Eds.), Parenting and the Internalization of Values: A Handbook of Contemporary Theory. John Wiley.

Mai, N., \& Paladini, C. (2013). Flexible circularities: Integration, return, and socio-economic instability within Albanian migration to Italy. In A. Triandafyllidou (Ed.), Circular Migration Between Europe and its Neighborhood. Choice or Necessity? (pp. 42-67). Oxford University Press.

Maliepaard, M., Gijsberts, M., \& Lubbers, M. (2012). Reaching the limits of secularization? Turkish- and Moroccan-Dutch Muslims in the Netherlands 1998-2006. Journal for the Scientific Study of Religion, 51(2), 359-367.

Maliepaard, M., \& Lubbers, M. (2013). Parental religious transmission after migration: The case of Dutch Muslims. Journal of Ethnic and Migration Studies, 39(3), 425-442.

Membretti, A., \& Quassoli, F. (2015). Discriminare in tempo di crisi: la relazione tra immigrati e agenzie immobiliari a Milano e Pavia. Mondi Migranti, 3, 169-189.

Molteni, F. (2017) Religious Change among Cohorts in Eastern Europe: A Longitudinal Analysis of Religious Practice and Belief in Formerly Communist Countries. Religion and Society in Central and Eastern Europe, 10(1), 35-53

Molteni, F. (2019) Anti-Immigration Attitudes in Europe, 2002-2016: A Longitudinal Test of the Group Conflict Theory. Polis, Ricerche e studi su società e politica, 2, 215-240.

Molteni, F. \& Biolcati, F. (2018) Shifts in religiosity across cohorts in Europe: A multilevel and multidimensional analysis based on the European Values Study. Social Compass, 65(3), 413-432.

Norris, P., \& Inglehart, R. (2011). Sacred and secular: Religion and politics worldwide (2nd ed.). Cambridge University Press.

Panichella, N., \& Cantalini, S. (2018). Lo Studio Quantitativo Dei Fenomeni Migratori. Dati, Prospettive e Strategie per Studiare Le Migrazioni. Polis (Italy), 32(3), 401-410.

Peach, C., \& Gale, R. (2003). Muslim, Hindus, and Sikhs in the new religious landscape of England. The Geographical Review, 93(4), 469-490.

Peixoto, J., Arango, J., Bonifazi, C., Finotelli, C., Sabino, C., Strozza, S., \& Triandafyllidou, A. (2012). Immigrants, markets and policies in Southern Europe. The making of an immigration model? In M. Okòlski (Ed.), European Immigrations. Trends, Structures and Policy Implications (pp. 107-147). Amsterdam University Press.

Perrotta, D. (2011). Vite in Cantiere: Migrazione e Lavoro Dei Rumeni in Italia. Bologna: il Mulino.

Pew Research Center. (2011). The future of the global Muslim population. http://www.pewforum.org/2011/ 01/27/the-future-of-the-global-muslim-population/.

Phalet, K., \& ter Wal, J. (2004). Moslim in Nederland. Netherlands Institute for Social Research.

Pisati, M. (2000). La domenica andando alla messa: Un'analisi metodologica e sostantiva di alcuni dati sulla partecipazione degli italiani alle funzioni. Polis, 14(1), 115-136.

Portes, A., \& Rumbaut, G. R. (2001). Legacies: The story of the immigrant second generation. University of California Press. 
Pruzan-Jorgensen, J. E. (2010). The Islamist movement in Morocco. In Main actors and regime responses. Danish Institute for International Studies (DIIS) Report.

Ricucci, R. (2017). Diversi Dall'Islam. Figli Dell'immigrazione e Altre Fedi. Il Mulino.

Roy, O. (2004). Globalised Islam. Hurst.

Sacchetto, D., \& Vianello, F. A. (2016). Unemployed migrants coping with the economic crisis. Romanians and Moroccans in Italy. Journal of International Migration \& Integration, 17(3), 839-852.

Sandor, S. D., \& Popescu, M. (2008). Religiosity and values in Romania. Transylvanian Review of Administrative Sciences, 22E, 171-180.

Smits, F., Ruiter, S., \& van Tubergen, F. (2010). Religious practices among Islamic immigrants: Moroccan and Turkish men in Belgium. Journal for the Scientific Study of Religion, 49(2), 247-263.

Soehl, T. (2017). Social reproduction of religiosity in the immigrant context: The role of family transmission and family formation-Evidence from France. International Migration Review, 51(4), 999-1030.

van Tubergen, F., \& Sindradóttir, J. Í. (2011). The religiosity of immigrants in Europ e: A cross-national study. Journal for the Scientific Study of Religion, 50(2), 272-288.

Vezzoni, C., \& Biolcati-Rinaldi, F. (2015). Church attendance and religious change in Italy, 1968-2010: A multilevel analysis of pooled datasets. Journal for the Scientific Study of Religion, 55(1), 100-118.

Voas, D., \& Fleischmann, F. (2012). Islam moves west: Religious change in the first and second generations. Annual Review of Sociology, 38(1), 525-545.

Warner, S., \& Wittner, J. G. (1998). Gatherings in Dimpora: Religious communities and the new immigration. Temple University Press.

Wilson, B. (1982). Religion in Sociological Perspective. Oxford University Press.

Wuthnow, R., \& Christiano, K. (1979). The effects of residential migration on church attendance in the United States. In R. Wuthnow (Ed.), The Religious Dimension: New Directions in Quantitative Research (pp. 257-276). Academic Press.

Yang, F., \& Ebaugh, H. R. (2001). Transformation in new immigrant religions and their global implications. American Sociological Review, 66(2), 269-288.

Zanfrini, L. (2019). The Challenge of Migration in a Janus-Faced Europe. Palgrave Pivot.

Zanfrini, L. (2020). Migrants and religion: Paths, issues, and lenses a multi-disciplinary and multi-sited study on the role of religious belongings in migratory and integration processes. Leiden-Boston: Brill.

Publisher's Note Springer Nature remains neutral with regard to jurisdictional claims in published maps and institutional affiliations. 